\title{
Implikasi Putusan Mahkamah Konstitusi No. 18/PUU-XVII/2019 Terhadap Hak Melakukan Parate Eksekusi Oleh Pemegang Jaminan Fidusia
}

\author{
Deystia Ayesha Rae \\ Magister Hukum Ekonomi, Fakultas Hukum, Universitas Indonesia \\ E-mail:deystia@gmail.com
}

\begin{abstract}
Abstrak. Penelitian ini meneliti mengenai implikasi Putusan Mahkamah Konstitusi No. 18/PUUXVII/2019 terhadap hak parate eksekusi yang melekat pada hak jaminan fidusia dan diberikan kepada kreditur selaku penerima objek jaminan fidusia. Putusan Mahkamah Konsitusi No. 18/PUU-XVII/2019 dikhawatirkan telah menghilangkan salah satu kekhususan dan/atau daya tarik yang ada pada jaminan fidusia, sehingga dapat menurunkan minat calon kreditur untuk dapat menyalurkan kredit kepada calon debitur. Hal tersebut tentu bertentangan dengan pertimbangan awal dari pembuat undang-undang dalam menyediakan suatu lembaga parate eksekusi, yaitu untuk memberikan perlindungan hukum kepada calon kreditur, dan meningkatkan minat calon kreditur untuk menyalurkan kredit sehingga dapat meningkatkan perekonomian negara.
\end{abstract}

Kata Kunci: fidusia, hak jaminan fidusia, objek jaminan fidusia, parate eksekusi.

Abstract. This paper examines the implication of Constitutional Court Decision No. 18/PUUXVII/2018 regarding parate eksekusi rights which exists in the fiduciary guaranty right and is given to the creditor as the recipient of the fiduciary object. It is feared that the Constitutional Court Decision No. 18/PUU-XVII/2019 has eliminated one of the specificities and/or attractiveness of the fiduciary guarantee, thereby, reducing the interest of prospective creditors to be able to provide credit to the prospective debtors. This is certainly in contrary to the initial considerations of legislators in providing parate eksekusi rights, which is to provide a legal protection to prospective creditors and increase the interest of prospective creditors to provide credit, therefore, improving the country's economy.

Keywords: fiduciary, fiduciary guaranty right, fiduciary object, parate eksekusi.

\section{PENDAHULUAN}

\section{Latar Belakang}

Jaminan pada hakikatnya diberikan untuk memberikan keyakinan kepada pihak pemberi utang selaku kreditor untuk menjamin adanya pembayaran utang-utang yang telah diberikan kreditor kepada penerima utang selaku debitor, yang timbul baik karena hukum, maupun timbul dari suatu perjanjian yang bersifat ikutan (assesoir) terhadap perjanjian pokok berupa perjanjian utang piutang. Bentuk jaminan yang diberikan dapat berupa jaminan kebendaan atau jaminan perorangan, dimana apabila jaminan diberikan dalam bentuk jaminan kebendaan, maka jaminan diberikan dengan atau tanpa penyerahan kekuasaan dan menikmati hasil dari objek jaminan tersebut, yang pada umumnya menimbulkan suatu hak kepada kreditor untuk menerima pembayaran utang terlebih dahulu dari debitor, dengan beberapa pengecualian, di mana pembayaran utang akan diambil dari hasil penjualan barang-barang yang dibebankan sebagai jaminan utang tersebut. Pengaturan mengenai pemberian jaminan di Indonesia lebih lanjut diatur dalam hukum jaminan. Sri Soedewi Masjhoen Sofwan memberikan definisi dari hukum jaminan yaitu:

"Mengatur konstruksi yuridis yang memungkinkan pemberian fasilitas kredit, dengan menjaminkan benda-benda yang dibelinya sebagai jaminan. Peraturan demikian harus cukup meyakinkan dan 
memberikan kepastian hukum bagi lembagalembaga kredit, baik dari dalam negeri maupun luar negeri. Adanya lembaga jaminan dan lembaga demikian, kiranya harus dibarengi dengan adanya lembaga kredit dengan jumlah, besar, dengan jangka waktu yang lama dan bunga yang relative rendah" (Sri Soedewi Masjhoen Sofwan, 1980:5).

Lebih lanjut, J. Satrio mendefinisikan hukum jaminan sebagai berikut:

"Peraturan hukum yang mengatur jaminanjaminan piutang seorang kreditur terhadap debitur" (Satrio, 1996:3).

Dalam hukum jaminan, diatur adanya jaminan secara umum dan jaminan secara khusus. Jaminan secara umum merupakan jaminan yang timbul dari undang-undang, sementara jaminan secara khusus merupakan jaminan yang timbul dari suatu perjanjian. Pemberian jaminan umum telah membuktikan bahwa hukum jaminan telah secara otomatis memberikan perlindungan kepada kreditur bagi pelunasan utang debitur, selain itu pemberian jaminan secara umum ini juga memberikan rasa aman (kepastian) bagi kreditur. Sedangkan pada jaminan secara khusus, jaminan dapat diberikan dalam 2 (dua) bentuk, yaitu jaminan kebendaan dan jaminan perorangan

Jaminan kebendaan dalam sifatnya yaitu memberikan hak kepada kreditor untuk menerima pembayaran utang terlebih dahulu dan memudahkan bagi pelunasan hak tagihnya, terdapat lembaga-lembaga yang merupakan keistimewaan dari lembaga jaminan khusus, yaitu salah satunya adalah lembaga Parate Eksekusi. Lembaga Parate Eksekusi ini memberikan hak bagi kreditur untuk melakukan penjualan objek jaminan atas kekuasaannya sendiri atau seolah-olah objek jaminan yang dijaminkan oleh debitur bagi pelunasan utangnya adalah miliknya sendiri, dengan sangat sederhana karena tidak melibatkan peran debitur dan tanpa izin hakim dan title eksekutorial. Berdasarkan hal tersebut, maka dapat dilihat bahwa lembaga Parate Ekeskusi telah memberikan kedudukan yang sangat terlindungi kepada kreditur, dikarenakan menempatkan kreditur seolah-olah ia merupakan pemilik dari objek jaminan kebendaan tersebut. Selanjutnya, terdapat 5 (lima) bentuk jaminan kebendaan sebagaimana diatur dalam sistem hukum Indonesia, yaitu:

a. Gadai, sebagaimana diatur di dalam Pasaal 1150 sampai dengan pasal 1160 Kitab Undang-Undang Hukum Perdata ("KUHPerdata");

b. Fidusia, sebagaimana diatur di dalam Undang-undang No. 42 Tahun 1999 tentang Jaminan Fidusia ("UUJF");

c. Hak Tanggungan, sebagaimana diatur di dalam Undang-Undang No. 4 Tahun 1996 tentang Hak Tanggungan Atas Tanah Beserta Benda-Benda yang Berkaitan Dengan Tanah ("UU Hak Tanggungan");

d. Hipotik, sebagaimana diatur di dalam [insert];

e. Resi Gudang, sebagaimana diatur di dalam Undang-Undang No. 9 Tahun 2006 sebagaimana diubah dengan Undang-Undang No. 9 Tahun 2011 tentang Sistem Resi Gudang.

Namun berkaitan dengan jaminan kebendaan dalam bentuk fidusia, pada tanggal 6 Januari 2020, Majelis Hakim Mahkamah Konstitusi melalui Putusan Mahkamah Konstitusi No. 18/PUU-XVII/2019 ("Putusan MK") telah mengabulkan sebagian uji materi atas Pasal 15 ayat (2), dan ayat (3) UUJF yang dianggap bertentangan dengan Undang-Undang Dasar 1945 (“UUD 1945”). Jaminan fidusia sendiri merupakan salah satu bentuk jaminan kebendaan dimana merujuk kepada ketentuan Pasal 1 ayat (1) UUJF merupakan suatu pengalihan hak kepemilikan suatu benda, yang didasarkan kepada kepercayaan dengan ketentuan bahwa benda yang menjadi objek jaminan fidusia tersebut dalam penguasaan pemilik benda tersebut. Salah satu karakteristik jaminan fidusia sebagai jaminan kebendaan adalah bentuknya yang memberikan hak untuk melakukan parate eksekusi kepada pemegang jaminan. 
Terakreditasi Peringkat 5 (No. SK: 85/M/KPT/2020)

Dengan terbitnya Putusan MK, selanjutnya maka dinyatakan bahwa pelaksanaan eksekusi atas Sertifikat Jaminan Fidusia harus dilakukan dan berlaku sama dengan pelaksanaan eksekusi putusan pengadilan yang telah berkekuatan hukum tetap, yang mana juga, terhadap jaminan fidusia yang tidak ada kesepakatan tentang cidera janji dan debitur keberatan untuk menyerahkan objek jaminan fidusia secara sukarela, maka segala mekanisme dan prosedur hukum dalam pelaksanaan eksekusi Sertifikat Jaminan Fidusia juga harus dilakukan dan berlaku sama dengan pelaksanaan eksekusi putusan pengadilan yang telah berkekuatan hukum tetap. Selain itu, Putusan MK juga menentukan bahwa adanya cidera janji tidak ditentukan secara sepihak oleh kreditur melainkan atas dasar kesepakatan antara kreditur dengan debitur atau atas dasar upaya hukum yang menentukan telah terjadinya cidera janji.

Berdasarkan hal tersebut di atas, maka dengan terbitnya Putusan MK telah meniadakan salah satu karakteristik khusus yang diberikan dalam jaminan kebendaan yaitu bagi kreditur untuk melakukan parate eksekusi, sehingga salah satu perlindungan yang diberikan kepada kreditur menjadi hilang, dan juga telah meniadakan sifat-sifat dari jaminan fidusia yang menjadi daya tarik bagi kreditur untuk bersedia memberi pinjaman kepada kreditur, yaitu sederhana, cepat, mudah, dan memberikan kepastian hukum bagi kreditur dalam hal terjadi cidera janji. Oleh karena itu, penulisan ini kemudian dilakukan untuk dapat memahami bagaimana jaminan fidusia diatur di dalam sistem fidusia, dan bagaimana Putusan MK mengubah karakteristik dari jaminan fidusia, yang sebagaimana telah diketahui sebelumnya, memberikan hak kepada pemegang jaminan fidusia untuk melakukan parate eksekusi.

\section{Rumusan Masalah}

Berdasarkan uraian di atas, maka dapat dirumuskan beberapa rumusan masalah yang akan dibahas dalam karya ilmiah ini, yaitu:
1. Bagaimana jaminan fidusia diatur di dalam sistem hukum di Indonesia?

2. Bagaimana parate eksekusi diatur di dalam jaminan fidusia?

3. Bagaimana implikasi terbitnya Putusan Mahkamah Konstitusi No. No. 18/PUUXVII/2019 terhadap hak parate eksekusi dalam jaminan fidusia?

\section{METODE PENELITIAN}

Penelitian ini merupakan penelitian yuridis normative, yang mengacu kepada norma hukum yang berlaku di peraturan perundangundangan. Metode penelitian yang digunakan di dalam penelitian ini adalah metode penelitian kepustakaan.

Tipe penelitian untuk penelitian ini adalah deskriptif karena memberikan data yang menjelaskan, memaparkan dan menggambarkan keadaan secara teliti. Pendekatan yang akan dilakukan di dalam penelitian ini adalah pendekatan secara normative. Pendekatan normative dilakukan dengan mempelajari bukubuku, bahan-bahan bacaan literatur peraturan perundang-undangan yang menunjang dan berhubungan sebagai penelaahan hukum terhadap kaidah yang dianggap sesuai dengan penelitian hukum tertulis.

Data yang akan dipakai dalam penelitian ini adalah data primer dan data sekunder. Data primer disini yaitu data yang diperoleh langsung dari objek penelitian lapangan yang berkaitan dengan permasalahan yang ada. Sedangkan pada data sekunder, bahan hukum yang dipergunakan adalah:

1. Bahan hukum primer, yang digunakan dalam penelitian ini adalah peraturan perundangundangan yaitu KUHPerdata dan Undangundang No. 42 Tahun 1999 tentang Jaminan Fidusia.

2. Bahan hukum sekunder, yaitu bahan-bahan yang memberikan informasi atau hal-hal yang berkaitan dengan isi bahan hukum primer serta implementasinya, yang berupa buku-buku yang membahas mengenai jaminan fidusia. 
3. Bahan hukum tersier, yaitu bahan-bahan yang memberikan petunjuk maupun penjelasan terhadap bahan hukum primer atau bahan hukum sekunder.

\section{PEMBAHASAN}

\subsection{Jaminan Fidusia Dalam Sistem Hukum Indonesia}

Latar belakang dari timbulnya lembaga jaminan fidusia dalam sistem hukum Indonesia adalah dikarenakan ketentuan undang-undang yang mengatur mengenai lembaga gadai (pand) mengandung banyak kekurangan serta tidak memenuhi kebutuhan masyarakat dan tidak mengikuti perkembangan masyarakat. Berdasarkan kekurangan tersebut maka timbul praktek lembaga jaminan fidusia untuk menjawab kekurangan dari lembaga jaminan gadai. Dalam perkembangannya, arrest Hoge Raad 1929 tanggal 25 Januari 1929 mengakui sahnya lembaga jaminan fidusia, dimana arrest ini terkenal dengan Bierbrouwerij Arrest. Pertimbangan dari Hoge Raad lebih menekankan kepada segi hukum dibandingkan segi kemasyarakatan, dimana Hoge Raad berpendapat bahwa perjanjian fidusia bukan merupakan perjanjian gadai dan tidak terjadi penyimpangan hukum. P.A.Stein kemudian berpendapat bahwa:

a. Fidusia tidak bertentangan dengan ketentuan undang-undang yang mengatur mengenai gadai dikarenakan tidak dilakukan perjanjian gadai pada fidusia;

b. Fidusia tidak bertentangan dengan ketentuan undang-undang yang mengatur mengenai hak jaminan bersama bagi kreditur, karena ketentuan mengenai hal tersebut berlaku bagi semua benda-benda bergerak maupun benda tetap dari debitur, sedangkan fidusia justru bendanya bukan hak dari debitur;

c. Ketentuan gadai sama sekali tidak dapat disimpulkan adana maksud dari pembentuk undang-undang bahwa jaminan utang hanya dimungkinkan diberikan atas benda bergerak yang tidak boleh berada dalam kekuasaan debitur;

d. Lembaga jaminan fidusia merupakan alas hak untuk melakukan perpindahan hak milik sebagaimana dimaksud di dalam Pasal 584 KUHPerdata;

e. Pemberian hak semata-mata diberikan hanya dimaksudkan sebagai pemberian jaminan, tanpa penyerahan nyata dari benda, dan perpindahan hak tersebut tidak memberikan semua akibat-akibat hukum sebagaimana yang terjadi pada perpindahan hak milik pada seharusnya.

Lembaga jaminan fidusia kemudian lahir di Indonesia melalui Arrest Hoggerechtshof 18 Agustus 1932 (BPM-Clynet Arrest) oleh pengaruh asas konkordansi, dan juga dipengaruhi oleh kebutuhan-kebutuhan yang mendesak dari pengusaha-pengusaha kecil, pengecer, pedagang menengah, dan pedagangan grosir yang memerlukan fasilitas kredit untuk perkembangan usahanya. Namun, pengaturan lebih lanjut mengenai jaminan fidusia baru kemudian dituangkan melalui UUJF pada tanggal 30 September 1999, dengan dilatarbelakangi oleh:

a. Adanya kebutuhan yang besar dan terus meningkat atas tersedianya dana, dan perlu diimbangi dengan adanya ketentuan hukum yang jelas yang mengatur mengenai lembaga jaminan, dalam rangka adanya kepastian hukum;

b. Jaminan fidusia merupakan salah satu bentuk lembaga jaminan yang sampai dengan saat itu masih berdasarkan kepada yurisprudensi, dan belum memiliki peraturan perundang-undangan yang lengkap dan komprehensif;

c. Untuk memenuhi kebutuhan hukum yang mengacu kepada pembangunan nasional dan untuk menjamin kepastian hukum bagi para pihak yang memiliki kepentingan, maka perlu dibuat suatu ketentuan mengenai jaminan fidusia, yang mana jaminan tersebut didaftarkan pada kantor pendafataran fidusia; 
d. Dalam jaminan fidusia, hak seseorang atas suatu benda menjadi jaminan atas seluruh utangnya, apabila kreditur tersebut kemudian tidak menepati kewajibannya, maka kreditur dapat dengan cepat dan mudah melaksanakan haknya terhadap debitur yang bersangkutan dengan mendapat kedudukan yang lebih tinggi dibandingkan kreditur-kreditur lainnya.

Lembaga jaminan fidusia berdasarkan ketentuan Pasal 1 ayat (4), Pasal 9, Pasal 10, dan Pasal 20 UUJF mengatur mengenai benda-benda yang dapat menjadi objek jaminan fidusia adalah sebagai berikut:

a. Benda tersebut harus dapat dimiliki dan dialihkan secara hukum;

b. Dapat atas benda berwujud dan/atau benda tidak berwujud, termasuk didalamnya piutang;

c. Benda bergerak;

d. Benda tidak bergerak yang tidak dapat diikat dengan hak tanggungan;

e. Benda tidak bergerak yang tidak dapat diikatkan dengan hipotek;

f. Baik atas benda yang sudah ada maupun terhadap benda yang akan diperoleh di kemudian hari. Dalam hal benda yang akan diperoleh dikemudian hari, tidak diperlukan suatu akta pembebanan fidusia tersendiri;

g. Dapat atas satu satuan atau jenis benda, dan dapat juga atas lebih dari satu jenis atau satuan benda;

h. Termasuk hasil dari benda yang telah menjadi objek jaminan fidusia;

i. Termasuk hasil klaim asuransi dari benda yang menjadi objek jaminan fidusia;

j. Benda persediaan (inventory, stock perdagangan).

Terhadap objek jaminan fidusia yang dibebankan dengan jaminan fidusia tersebut kemudian sebagaimana merujuk kepada ketentuan Pasal 11 UUJF, wajib untuk dilakukan pendaftaran fidusia kepada Kantor Pendaftaran Fidusia yang berada di bawah naungan Kementerian Hukum dan Hak Asasi Manusia Republik Indonesia.
Kemudian, sebagai bukti bahwa penerima memiliki hak atas objek jaminan fidusia tersebut, maka kemudian terbitlah Sertifikat Jaminan Fidusia yang mempunyai kekuatan pembuktian sebagai suatu akta otentik, dimana Sertifikat Jaminan Fidusia diterbitkan oleh Kantor Pendaftaran Fidusia kepada kreditur selaku penerima jaminan fidusia. Hal ini juga sebagai perwujudan ketentuan Pasal 14 ayat (3) UUJF yang menentukan bahwa jaminan fidusia baru ada pada saat dilakukan pendaftaran objek jaminan fidusia di Kantor Pendaftaran Fidusia.

Dalam hal debitur kemudian melakukan cidera janji (wanprestasi) terhadap perjanjian utang piutang, maka kemudian kreditur dalam melakukan eksekusi atas objek jaminan fidusia tersebut. Terdapat 3 (tiga) cara eksekusi objek jaminan fidusia, yaitu:

a. Pelaksanaan titel eksekutorial oleh kreditur. Yang dimaksud dengan titel eksekutorial (alas hak eksekusi) ini adalah tulisan yang mengandung pelaksanaan putusan pengadilan, yang memberikan dasar untuk penyitaan dan lelang sita (executorial verkhoop) tanpa perantara Hakim;

b. Penjualan benda yang menjadi objek jaminan fidusia atas kekuasaan kreditur sendiri melalui pelelangan umum serta mengambil pelunasan piutangnya dari hasil penjualan; dan

c. Penjualan di bawah tangan yang dilakukan berdasarkan kesepakatan kreditur dan debitur jika dengan cara demikian dapat diperoleh harga yang tertinggi yang menguntungkan para pihak. Penjualan ini dilakukan setelah lewat waktu 1 (satu) bulan sejak diberitahukan secara tertulis oleh kreditur dan debitur kepada pihak yang berkepentingan dan diumumkan sedikitnya dalam 2 (dua) surat kabar yang beredar di daerah yang bersangkutan (Pasal 29 UUJF).

\subsection{Pengaturan Mengenai Parate Eksekusi Dalam Jaminan Fidusia \\ Jaminan fidusia sebagai salah satu bentuk jaminan kebendaan memberikan}


kedudukan kepada pemegang jaminan fidusia, yang lebih tinggi dibandingkan kreditur-kreditur lain jaminan. Jaminan fidusia sebagai jaminan kebendaan memberikan kelebihan-kelebihan secara hukum, dimana selain memerikan hak prioritas pertama atas hasil eksekusi barang jaminan untuk dibayar utang-utangnya terlebih dahulu sebelum utang-utang kreditur lainnya dibayarkan, namun juga memberikan kesempatan eksekusi yang mudah dimana dalam hal ini, eksekusi jaminan utang tersebut tidak seperti eksekusi biasa yang harus menempuh jalur pengadilan melalui proses gugatan biasa yang memakan waktu yang lama. Bahkan dalam hal-hal tertentu, objek jaminan fidusia dapat dilakukan eksekusi sendiri oleh kreditur (parate eksekusi) tanpa perlu campur tangan pengadilan sama sekali. Lebih lanjut mengenai parate eksekusi menurut Subekti, merupakan suatu hak untuk menjalankan sendiri atau mengambil sendiri apa yang menjadi hak nya, dalam arti tanpa perantara hakim, yang ditujukan atas suatu barang jaminan untuk selanjutnya menjual sendiri barang tersebut.

Melihat kepada sisi sejarah, diterimanya lembaga parate eksekusi sebagai sarana pelunasan utang debitur telah mengalami perdebatan yang sengit di Parlemen Belanda pada saat itu. Pembuat undang-undang dihadapkan pada dua realitas yang dilematis, yaitu disatu sisi lembaga pemberi kredit menunjukkan kecenderungan minat yang menurun dalam memberikan bantuan kredit dikarenakan adanya ketakutan dari sisi kreditur untuk melakukan penagihan apabila debitur melakukan cidera janji (wanprestasi), dikarenakan kreditur yang telah memberikan kredit memiliki kepentingan untuk dapat memutarkan harta dan asetnya sehingga memberikan keuntungan baginya. Apabila dikemudian hari debitur mengalami gagal bayar dan/atau cidera janji (wanprestasi), maka tentu hal tersebut akan merugikan kreditur, dimana kreditur kemudian perlu melakukan penagihan dan pelunasan melalui proses gugatan di pengadilan yang tentu akan memakan waktu yang lama, hal ini tidak sebanding dengan pengorbanan yang telah kreditur keluarkan untuk memperoleh pengembalian kembali kredit yang telah diberikannya. Namun disisi lain, pembuat undang-undang juga dihadapkan dengan kenyataan banyaknya rakyat kecil saat itu membutuhkan pinjaman kredit untuk menjalankan kegiatan usahanya.

Pada saat akhir pengesahan Burgerlijke Wetboek, pembuat undang-undang pada akhirnya memilih untuk menyelamatkan rakyat kecil dan menengah untuk meningkatkan perekonomian negara, dengan mengakomodir adanya lembaga parate eksekusi sebagai sarana bagi kreditur untuk dapat menjual objek jaminan dalam Burgerlijke Wetboek. Mengenai hal tersebut, J. Satrio menjelaskan bahwa:

".... bahwa yang namanya menagih utang melalui suatu gugatan di Pengadilan, dari mulai gugatan dimaksukkan sampai pada pelaksanaan eksekusi, baik pada zaman dahulu maupun sekarang, memakan waktu yang lama, dan sehubungan dengan itu memakan biaya yang relative besar. Akibatnya, bank-bank sebagai lembaga pemberi kredit yang resmi, yang dalam praktek paling banyak menggunakan lembaga gadai akan enggan untuk memberikan kredit kepada nasabah kecilkecil, karena kalau terjadi, bahwa nantinya kredit itu macet, maka waktu yang tersita untuk mengurus penagihan akan lama sekali, dan biayanya bisa tidak imbang dengan tagihan yang hendak dikerja melalui gugatan itu (A.S. van Nierop, Hypotheek, 1937, hal. 155-156). Kalau demikian, maka nasabah-nasabah kecil terpaksa akan mencari pinjaman uangnya kepada para lintah darat, yang pada umumnya tidak menuntut banyak syarat, kecuali bunga yang tinggi. Pembuat undang-undang pada waktu itu dihadapkan pada pilihan, ia biarkan orang kecil, yang membutuhkan pinjaman dicekik oleh lintah darat, atau ia berikan kepada Bank suatu sarana yang mudah dalam mengambil 
pelunasan, yang dengan perkaraan lain menyetujui pemberian hak parate eksekusi. Pembuat undang-undang ternyata, demi untuk melindungi rakyat kecil, memilih yang kedua."

Mengenai parate eksekusi tersebut lebih lanjut telah diatur di dalam Pasal 1155 KUHPerdata, yang berbunyi sebagai berikut:

"apabila oleh para pihak tidak telah diperjanjikan lain, maka si berpiutang adalah berhak jika si berutang atau si pemberi gadai bercedera janji, setelah tenggang waktu yang ditentukan lampau, atau jika tidak telah ditentukan suatu tenggang waktu, setelah dilakukannya suatu peringatan untuk membayar, menyuruh menjual barang gadainya di muka umum menurut kebiasaankebiasaan setempat serta atas syaratsyarat yang lazim berlaku, dengan maksud untuk mengambil pelunasan jumlah piutangnya beserta bunga dan biaya dari pendapatan penjualan tersebut."

Lebih lanjut, jaminan Fidusia melalui UUJF memiliki tujuan untuk dapat melaksanakan proses eksekusi yang cepat, sederhana, efisien, dan mengandung kepastian hukum. Berdasarkan hal tersebut, kemudian parate eksekusi pada jaminan fidusia diatur di dalam 2 (dua) pasal, yaitu Pasal 15 ayat (3) UUJF dan Pasal 29 ayat (1) huruf b UUJF, yang masing-masing menyatakan sebagai berikut:

Pasal 15 ayat (3) UUJF:

"Apabila debitur cidera janji, Penerima Fidusia mempunyai hak untuk menjual Benda yang menjadi objek Jaminan Fidusia atas kekuasaannya sendiri." Pasal 29 ayat (1) huruf b UUJF:

"penjualan Benda yang menjadi objek Jaminan Fidusia atas kekuasaan Penerima Fidusia sendiri melalui pelelangan umum serta mengambil pelunasan piutangnya dari hasil penjualan."
Pasal 15 ayat (3) UUJF telah memberikan dasar hukum bagi kreditur untuk melaksanakan parate eksekusi. Kekuatan parate eksekusi jaminan fidusia adalah secara langsung dapat dilaksanakan tanpa melalui peradilan dan bersifat final dan mengikat para pihak untuk melaksanakannya. Kemudian selanjutnya melalui Pasal 29 ayat (1) huruf b UUJF, kreditur dapat melaksanakan eksekusi berdasarkan kekuasaannya sendiri, dengan melakukan penjualan objek jaminan fidusia melalui pelelangan umum. Sehingga berdasarkan hal tersebut, kreditur dapat langsung menghubungi juru lelang dan meminta agar atas objek jaminan dilakukan pelelangan.

Atas hal tersebut, maka keistimewaan dari hak parate eksekusi dalam jaminan fidusia adalah kreditur dapat menjual barang-barang jaminan sesudah debitur cidera janji tanpa melalui prosedur penyitaan terlebih dahulu, tanpa melibatkan juru sita, tanpa perantara dan izin hakim, sehingga ia seolah-olah melakukan lelang atas barang miliknya sendiri. Hak parate eksekusi ini telah memberikan kreditur suatu sarana yang lebih murah, lebih sederhana, dan lebih siap untuk setiap waktu diterapkan. Maka dari itu, kreditur dapat dikatakan memiliki sarana pengambilan pelunasan yang tidak hanya lebih didahulukan (separatis) namun juga lebih sederhana sehingga mempunyai sarana eksekusi yang siap di tangan.

Selain itu, berdasarkan ketentuan Pasal 15 ayat (3) UUJF dan Pasal 29 ayat (1) huruf b UUJF, dapat dilihat bahwa hak parate eksekusi di dalam jaminan fidusia diberikan oleh undangundang (by law) tanpa perlu diperjanjikan terlebih dahulu oleh para pihak. Bahkan, pembuat undang-undang membuka mekanisme eksekusi objek fidusia dengan lembaga parate eksekusi (salah satu cara disamping pelaksanaan titel eksekutorial dan penjualan bawah tangan).

\subsection{Implikasi Terbitnya Putusan Mahkamah Konstitusi No. No. 18/PUU-XVII/2019 terhadap Hak Parate Eksekusi Dalam Jaminan Fidusia}


Putusan MK telah menyatakan bahwa ketentuan yang diatur di dalam Pasal 15 ayat (2) beserta penjelasannya dan ayat (3) UUJF telah bertentangan dengan UUD 1945. Frasa yang terkandung dalam dalam Pasal 15 ayat (2) dan (3) yaitu "kekuatan eksekutorial" dan "sama dengan putusan pengadilan yang berkekuatan hukum tetap" perlu untuk disesuaikan dengan pemaknaan Mahkamah Konstitusi terhadap norma yang terdapat dalam Pasal 15 ayat (2) UUJF yaitu "terhadap jaminan fidusia yang tidak ada kesepakatan tentang cidera janji dan debitur keberatan menyerahkan secara sukarela objek yang menjadi jaminan fidusia, maka segala mekanisme dan prosedur hukum dalam pelaksanaan eksekusi Sertifikat Jaminan Fidusia harus dilakukan dan berlaku sama dengan pelaksanaan eksekusi putusan pengadilan yang telah berkekuatan hukum tetap."

Perbedaan ketentuan yang diatur di dalam Pasal 15 ayat (2) beserta penjelasannya dan ayat (3) UUJF sesudah Putusan MK dibacakan adalah sebagai berikut:

\begin{tabular}{|c|c|}
\hline \multicolumn{2}{|c|}{\begin{tabular}{c|c} 
UU FIDUSIA & PUTUSAN M \\
Pasal 15 ayat (2) UUJF
\end{tabular}} \\
\hline \multicolumn{2}{|c|}{ Pasal 15 ayat (2) UUJF } \\
\hline $\begin{array}{l}\text { Sertifikat Jaminan } \\
\text { Fidusia sebagaimana } \\
\text { dimaksud dalam ayat } \\
(1) \text { mempunyai } \\
\text { kekuatan eksekutorial } \\
\text { yang sama dengan } \\
\text { putusan pengadilan } \\
\text { yang telah } \\
\text { memperoleh kekuatan } \\
\text { hukum tetap }\end{array}$ & $\begin{array}{l}\text { Pasal } 15 \text { ayat (2) UU } \\
\text { Fidusia sepanjang } \\
\text { frasa "kekuatan } \\
\text { eksekutorial" } \\
\text { frasa "sama dengan } \\
\text { putusan pengadilan } \\
\text { yang berkekuatan } \\
\text { hukum } \\
\text { bertentangan } \\
\text { 1945 detap" } \\
\text { mempunyai kekuatan } \\
\text { hukum tidak } \\
\text { sepanjang mengikat } \\
\text { dimaknai "terhadap } \\
\text { jaminan fidusia yang } \\
\text { tidak tidak } \\
\text { kesepakatan tentang } \\
\text { cidera } \\
\text { (wanprestasi) } \\
\text { debitur dan } \\
\text { menyerahkan } \\
\text { keberatan } \\
\text { secara }\end{array}$ \\
\hline
\end{tabular}

sukarela objek yang menjadi jaminan fidusi, maka segala mekanisme dan prosedur hukum dalam pelaksanaan eksekusi Sertifikat Jaminan Fidusia harus dilakukan dan berlaku sama dengan pelaksanaan eksekusi putusan pengadilan yang telah berkekuatan hukum tetap.

\section{Penjelasan Pasal 15 ayat (2) UUJF}

Dengan ketentuan ini, Penjelasan Pasal 15 yang dimaksud ayat (2) UU Fidusia dengan "kekuatan sepanjang frasa eksekutorial" adalah "kekuatan langsung dapat eksekutorial" dilaksanakan tanpa bertentangan dengan melalui pengadilan dan bersifat final serta mengikat para pihak untuk melaksanakan putusan tersebut.
UUD 1945 dan tidak mempunyai kekuatan hukum mengikat sepanjang tidak dimaknai "terhadap jaminan fidusia yang tidak ada kesepakatan tentang cidera janji dan debitur keberatan menyerahkan secara sukarela objek yang menjadi jaminan fidusia, maka segala mekanisme dan prosedur hukum dalam pelaksanaan eksekusi Sertifikat Jaminan Fidusia harus dilakukan dan berlaku sama dengan pelaksanaan eksekusi putusan pengadilan 


\begin{tabular}{|c|c|}
\hline & $\begin{array}{l}\text { yang berkekuatan } \\
\text { hukum tetap". }\end{array}$ \\
\hline \multicolumn{2}{|c|}{ Pasal 15 ayat (3) UUJF } \\
\hline $\begin{array}{lr}\text { Apabila debitur cidera } \\
\text { janji, } & \text { Penerima } \\
\text { FIdusia mempunyai } \\
\text { hak untuk menjual } \\
\text { Benda yang } & \text { menjadi } \\
\text { objek } & \text { Jaminan } \\
\text { Fidusia } & \text { atas } \\
\text { kekuasaannya sendiri. }\end{array}$ & $\begin{array}{l}\text { Pasal } 15 \text { ayat (3) UU } \\
\text { Fidusia sepanjang } \\
\text { frasa "cidera janji" } \\
\text { bertentangan dengan } \\
\text { UUD } 1945 \text { dan tidak } \\
\text { mempunyai kekuatan } \\
\text { hukum mengikat } \\
\text { sepanjang tidak } \\
\text { dimaknai bahwa } \\
\text { "adanya cidera janji } \\
\text { tidak ditentukan } \\
\text { secara sepihak oleh } \\
\text { kreditur melainkan } \\
\text { atas dasar } \\
\text { kesepakatan antara } \\
\text { kreditur dengan } \\
\text { debitur atau atas } \\
\text { dasar upaya hukum } \\
\text { yang menentukan } \\
\text { telah terjadinya } \\
\text { cidera janji". }\end{array}$ \\
\hline
\end{tabular}

Berdasarkan Putusan MK tersebut di atas, maka dampat disimpulkan dengan jelas bahwa dalam hal terjadi cidera janji (wanprestasi) yang dilakukan oleh debitur atas perjanjian utang piutang, kreditur hanya dapat melaksanakan hak parate eksekusi berdasarkan titel eksekutorial yang terdapat pada Sertifikat Jaminan Fidusia, hanya apabila terdapat kesepakatan tentang cidera janji (wanprestasi) antara debitur dan kreditur, dan debitur telah secara sukarela menyerahkan objek jaminan fidusia untuk dilakukan eksekusi oleh kreditur. Namun, apabila tidak terdapat kesepakatan tentang cidera janji antara kreditur dan debitur, maka pernyataan adanya cidera janji (wanprestasi) harus berdasarkan putusan pengadilan yang telah berkekuatan hukum tetap.

Dengan adanya Putusan MK tersebut tentu dapat menghilangkan minat calon kreditur untuk dapat memberikan pinjaman kepada calon debitur yang hendak memberikan jaminan kebendaan berupa jaminan fidusia. Tentu tidak dapat dipungkiri bahwa jaminan fidusia memiliki peran yang sangat penting dalam menjunjang pertumbuhan ekonomi di Indonesia, yang mana salah satunya dapat dilihat dari indikator pemberian kredit. Jaminan fidusia dianggap sebagai bentuk jaminan yang sederhana, cepat, mudah, dan memberikan kepastian hukum bagi kreditur dalam hal terjadi cidera janji (wanprestasi) oleh debitur, dikarenakan kreditur dapat dengan cepat dan mudah menggunakan hak parate eksekusi yang melekat pada jaminan fidusia tersebut dalam pelaksanaan eksekusinya.

Selain itu, ketentuan Pasal 15 ayat (2) dan (3) UUJF merupakan ketentuan yang memberikan kekhususan bagi lembaga jaminan fidusia dibandingkan dengan jaminan lainnya untuk mengikat kreditur dan debitur, yang memberikan kepada kreditur suatu keutamaan (preferen). Hak khusus yang dimiliki oleh kreditur jaminan fidusia ini sudah diatur di dalam Pasal 1131 dan 1132 KUHPerdata. Dengan munculnya Putusan MK, secara langsung telah menghilangkan kekhususan yang dimiliki oleh lembaga jaminan fidusia, sehingga kreditur tidak lagi memiliki kekuasaan untuk mengambil pelunasan dari penjualan objek jaminan dalam hal debitur melakukan cidera janji (wanprestasi). Sehingga berdasarkan hal tersebut, kreditur tidak lagi dapat secara utuh memanfaatkan hak parate eksekusi yang melekat pada objek jaminan fidusia yang diberikan kepadanya.

\section{KESIMPULAN}

Lembaga jaminan fidusia merupakan suatu lembaga jaminan yang memungkinkan bagi debitur untuk tetap menggunakan dan/atau memanfaatkan objek jaminannya, baik itu untuk melanjutkan kegiatan usahanya maupun untuk membantu memperoleh dana dalam rangka pengembalian kredit yang telah diterimanya dari kreditur. Kreditur disisi lain perlu untuk mendapatkan kepastian hukum akan adanya pengembalian kredit, mengingat pada jaminan 
fidusia, objek jaminan tidak berada di bawah penguasaan kreditur, atau untuk menjamin ada upaya hukum yang cepat dan sederhana dalam rangka melakukan eksekusi atas objek jaminan, dalam hal debitur melakukan cidera janji (wanprestasi) dikemudian hari.

Parate eksekusi kemudian menjadi suatu khususan yang melekat pada jaminan fidusia, yang memberikan hak kepada kreditur untuk melakukan penjualan atas objek jaminan tanpa perlu adanya campur tangan pengadilan.

Namun, dengan dibacakannya Putusan MK, kreditur pemegang jaminan fidusia saat ini tidak dapat lagi melaksanakan hak parate eksekusi berdasarkan titel eksekutorial yang terdapat pada Sertifikat Jaminan Fidusia, terkecuali terdapat kesepakatan tentang cidera janji (wanprestasi) antara debitur dan kreditur, dan debitur telah secara sukarela menyerahkan objek jaminan fidusia untuk dilakukan eksekusi oleh kreditur. Hal ini secara terang telah menghilangkan kekhususan pada jaminan fidusia, dan berpotensi menghilangkan hak kreditur yang diutamakan untuk menerima pengembalian (preferen), sebagai pemegang jaminan kebendaan, dikarenakan kreditur tidak dapat lagi secara cepat dan sederhana melakukan eksekusi objek jaminan seketika saat debitur melakukan cidera janji (wanprestasi), dan tetap harus melalui proses gugatan di pengadilan sebagaimana kreditur tanpa jaminan kebendaan, yang tentu akan memakan waktu yang lama.

\section{DAFTAR REFERENSI}

Fuady Munir. Konsep Hukum Perdata. Cet. 3. Jakarta: PT RajaGrafindo Persada, 2016.

HS, H. Salim. Perkembangan Hukum Jaminan di Indonesia. Cet. 10. Jakarta: PT RajaGrafindo Persada, 2017.

Subekti, Pelaksanaan Perikatan, Eksekusi Riil dan Uang Paksa, Dalam: Penemuan Hukum dan Pemecahan Masalah Hukum. Jakarta: Proyek Pengembangan Teknis Yudisial, MARI, 1990.

Indonesia. Kitab Undang-Undang Hukum Perdata [Burgerlijk Wetboek], diterjemahkan oleh R. Subekti. Jakarta: Pradnya Paramita, 1996.

Indonesia. Undang-Undang Jaminan Fidusia, UU No. 42 Tahun 1999, LN No. 168 Tahun 1999, TLN No. 3889.

Angrraeni, Nenden Dewi. "Analisis Perlindungan Hukum Pemegang Jaminan Fidusia Studi Kasus Putusan Mahkamah Agung Nomor 1602/Pdt/2007" Tesis Magister Universitas Indonesia. Depok. 2012.

Fitriasti, Yasmine Nurul. "Analisis Yuridis Pelaksanaan Parate Eksekusi Jaminan Fidusia (Studi: PT Gemilang Usaha Persada Finance)" Tesis Kenotariatan Universitas Indonesia, Depok, 2010.

Pardede, Marulak. "Laporan Akhir Penelitian Hukum tentang Implementasi Jaminan Fidusia Dalam Pemberian Kredit di Indonesia" Badan Pembinaan Hukum Nasional Departemen Hukum dan HAM RI (2006). Hlm. 28.

Anggoro, Teddy. "Parate Eksekusi: Hak Kreditur, Yang Menderogasi Hukum Formil (Suatu Pemahaman Dasar dan Mendalam)" Jurnal Hukum dan Pembangunan Tahun Ke-3 No. 4 (Oktober-Desember 2007). Hlm. 536 555.

Mahkamah Konstitusi Republik Indonesia. Putusan No. 18/PUU-XVII/2019.

Cardima, Aska dan Hadyan Iman Prasetya. https://www.djkn.kemenkeu.go.id/kpknl -bekasi/baca-artikel/12953/PUTUSANMAHKAMAH-KONSTITUSINOMOR-18PUU-XVII2019-APAIMPLIKASINYA-BAGI-PROSES. Diakses 8 Januari 2021 pukul 22:04 WIB. Huzaini, Moh. Dani. "Butuh Aturan Lebih Detail, Parate Eksekusi Bermanfaat dalam Sistem Jaminan" https://www.hukumonline.com/berita/ba ca/lt5ce0bc2dc9da8/butuh-aturan-lebihdetil--parate-eksekusi-bermanfaatdalam-sistem-jaminan. Diakses 8 Januari 2021, pukul 22:39 WIB. 